\title{
Island-raised but foreign-made: lived experiences, transnational relationships, and expressions of womanhood among Cape Verdean migrant women in Greater Lisbon
}

\author{
Kaian Lam \\ Centre for International Studies, ISCTE-University Institute of Lisbon, Portugal \\ Ka_lan_Lam@iscte-iul.pt
}

\begin{abstract}
Cape Verdeans have migrated to many parts of the world. In Portugal, they are prominent demographically and socially. The archipelago of Cape Verde presents a unique combination of colonial past, immigration history and geographical features that complexifies a study of interpersonal and spatial relationships. The present study has two aims. It seeks to illustrate how Cape Verdean migrant women in Greater Lisbon live, define and negotiate their relationships with people and places, given the transnational configuration of contemporary migration. It also attempts to highlight how these women exercise creativity in expressions and assertions of womanhood. Based on fieldwork, I suggest that Cape Verdean migrant women are historically, socially, and culturally situated subjects. Not only do they possess the capacity to forge meaningful relationships, but they also navigate a sea of multiple and overlapping identities and belongings. They reassess and appropriate interpersonal and spatial relationships with reference to distinct ideas and criteria drawn from their migratory experiences. Taken together, their lived experiences reflect on their self-image as women, mothers, migrants and citizens.
\end{abstract}

Keywords: Cape Verde, diaspora, islands, female migration, gender, identity, transnationalism

https://doi.org/10.24043/isj.71

(C) 2019-Institute of Island Studies, University of Prince Edward Island, Canada.

\section{Introduction: literature, theory and method}

Cape Verde is a former colony of Portugal, first discovered in 1460 by Diogo Gomes. Of the archipelago's ten islands, nine have been inhabited at different periods. Historical involvement in European colonialization and transatlantic slave trade produced a creole population. Located in the Atlantic Ocean and the Sahel, Cape Verde experienced devastating droughts and famines that forced people to work as contracted labourers or to emigrate. Currently, the estimated resident population of Cape Verde is just above 530,000 (Cape Verde National Statistics Institute, 2016). It is generally believed that this figure is smaller than the total of its diasporic communities. With some of the earliest records of free emigrants from West Africa, Cape Verdean migration has deep historical roots and constitutes an important national marker (Carreira, 1984, 1977). A Cape Verdean saying goes, “T'e na Lua ten Kabu'verdiánu”" ("Even on the moon there are Cape Verdeans") (Góis, 2005, p. 255).

Cape Verde presents a unique combination of colonial past, immigration history and geographical features that complexifies a study of interpersonal and spatial relationships. Portugal, the former coloniser, hosts a large Cape Verdean diaspora, and Cape Verdeans form the most numerous African community in Portugal (Batalha \& Carling, 2008). And yet, Cape Verde has a peripheral status in African Studies and it is common to hear that "Cape Verde is 
not Africa," a victim of both colonialist and continentalist constructions (Baldacchino, 2013; Ducros, 2018). Africa is often seen as a continent, neglecting its islands. Just as the Caribbean is unrightfully reduced to 'little Africa' or 'little England' (Pugh, 2013), Cape Verde is called 'Little Brazil', oversimplifying and depoliticizing the archipelago's relations with the world. While Cape Verde can be compared with the Azores (Vale, 2018), Madeira or São Tomé (Garfield, 2015; Seibert, 2014), it also merits case studies of its own (Nolasco, 2018; Oliveira, 2018).

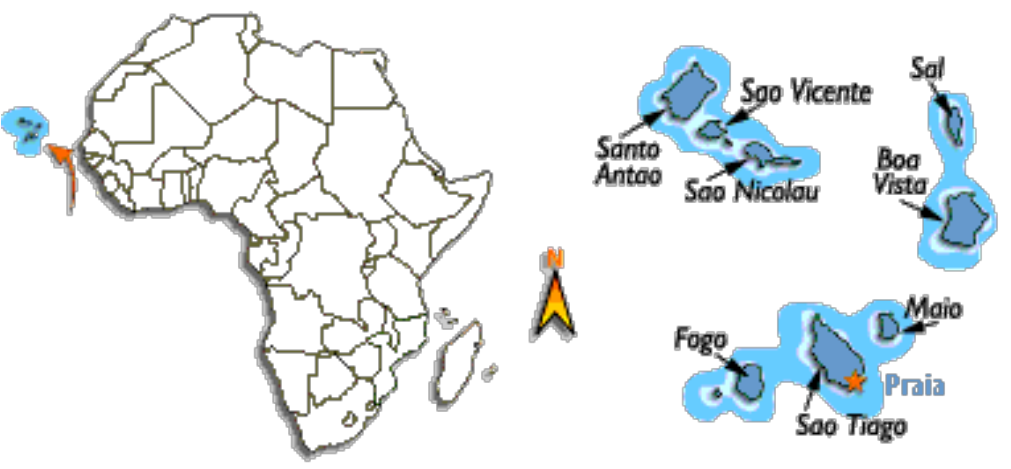

Figure 1: Map of Cape Verde. Source: https://dre.pt/web/guest/cabo-verde

The present study uses Cape Verde's status as an archipelago to inform a discussion of its mainland diaspora. It has two overall aims. First, it attempts to illustrate how Cape Verdean migrant women in Greater Lisbon (whom I shall call Caboverdianas) live, define and negotiate their relationships with people and places, given the transnational configuration of contemporary migration. Second, it seeks to highlight how these women exercise creativity in expressions and assertions of womanhood. Their voices are important because "the smaller, poorer or less populated the island gets, the more likely is it that its web, textual and literary content is dictated and penned by "others" (Baldacchino, 2008, p. 38). For these women, emigration is, on the one hand, a part of personal development contoured by islandness in a process that strengthens "feelings of distinction and possession" (Grydehøj, 2018, p. 9) and, on the other hand, a part of the "anchorage and drift" of Cape Verdean identity (Compan, 2018). For them, 'island' is what they perform and experience; it is not merely what they represent bearing in mind that it is possible to view islandness as a positive action and to approach place as a kind of practice (Vannini \& Taggart, 2013).

Cape Verdeans think about their society not just as an island society, but also as a global community, Cape Verde being the sum of the islands and the global diaspora. Therefore, their experiences also need to be understood in transnational terms. As part of a broader phenomenon of globalization, 'transnationalism' was originally used to refer to the processes by which immigrants connect their countries of origin and settlement and build social fields (Glick Schiller et al., 1992). It is open to knowledge of migration, society and culture; it is agency-oriented and acknowledges the life trajectories of individuals and families. Furthermore, engendered migration experiences are targeted (Morokvasic, 1984). The present study interprets the intercultural exposures and interactions of Caboverdianas in light of general cultural theories (Bourdieu, 1984; Williams, 1983), intercultural communication (Welsch, 1999), diasporic identities (Hall, 1996), and the positivity and creativity of everyday practices (Certeau, 1984) in a global world (Appadurai, 1996).

It is generally agreed that the first Caboverdianas to go abroad were from the island of São Nicolau (Andall, 1999). They departed for Italy through the mediation of Catholic friars to work as live-in domestic helpers for traditional well-to-do families in the 1960s. They formed a unique wave of emigration and were exclusively female. With regard to Portugal, Cape Verdean emigration was a male phenomenon up to the 1980s as Caboverdianas only came to join their 
husbands in shantytowns on the Lisbon periphery in the 1970s and 1980s (Batalha, 2004). Góis (2005) characterizes Cape Verdean mobility as "low-intensity transnationalism," as opposed to "high-intensity transnationalism," the family being the main transnational component. Within the Cape Verdean family, attention has been paid to the women (Åkesson et al., 2012; Challinor, 2015; Grassi \& Évora, 2007; Lobo, 2014; Silva \& Fortes, 2011). The present study contributes to the literature by presenting an integrated portrayal of Caboverdianas. Further, it updates current knowledge about Cape Verdean transnational migration and its diverse manifestations with new testimonies and life histories. Fieldwork coincided with the moments when the Portuguese economy revived from the international economic crisis and subsequent austerity measures. This study recognizes the peculiarities of Portugal as a migrantreceiving country and presents it as lived, felt and experienced by Caboverdianas.

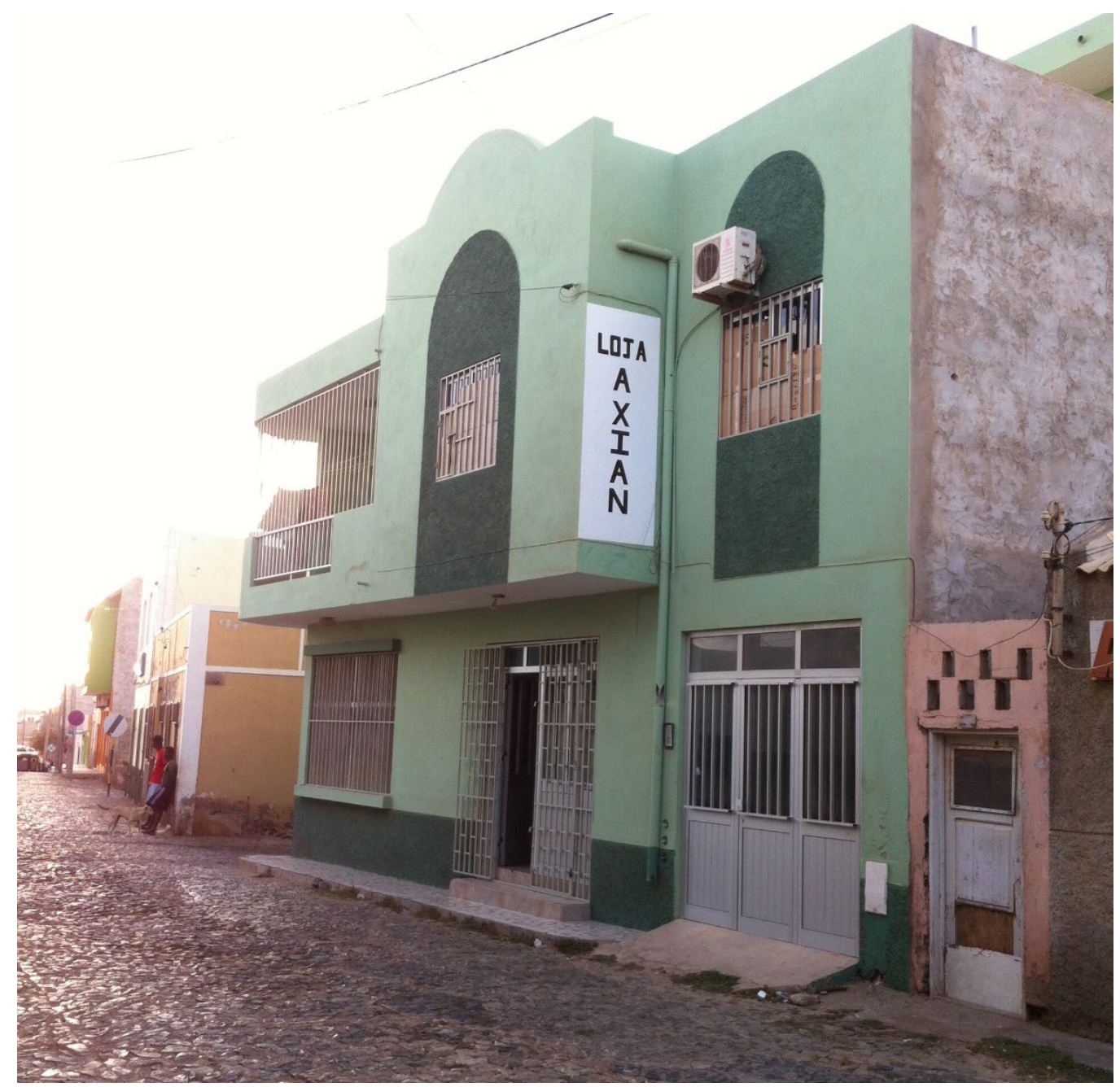

Figure 2: A Chinese shop among many others on Sal island, Cape Verde. (C) Kaian Lam

Fieldwork was conducted among Cape Verdeans in Greater Lisbon from June 2015 to March 2016. Primary data was obtained through semi-structured interviews, participant observation and collection of life histories. I started by joining a choir organized by a grassroots Cape Verdean association, presenting myself as a student of Portuguese and someone interested in Cape Verdean Creole and culture. The choir was a social group in disguise, with a preponderant female presence, and I was quickly accepted for being female and different, boosting the diversity profile of the choir. I was invited to eat at my informants' homes. Other times, I proposed to visit them. I also participated in miscellaneous cultural events. In addition, I drew on ten months' living experience in a neighbourhood populated mainly by immigrants, 
especially from the Cape Verdean island of Santiago. In order to embrace the experiences of diverse Cape Verdeans, I travelled by train regularly to another neighbourhood farther away to meet those from the windward islands. In April 2016, I stayed two weeks with a host family on Sal island in Cape Verde itself. Portuguese was the main language used in fieldwork. For better comprehension of native expressions, I attended additional Creole training at another Cape Verdean Association. Being Chinese, Cape Verdeans liked to greet me with a condescending comment about my compatriots in their country: "Os chineses não falam português. Falam crioulo. Até falam crioulo melhor do que eu." ("The Chinese do not speak Portuguese. They speak Creole. They even speak better Creole than I do."). Merely conducting research in more than one location is not the main concern (Hannerz, 2003). There are different means of contacting people besides face-to-face communication so that direct human contact is far from being the only credible source of primary data. I maintained contacts with Cape Verdeans through telephone calls and messages over the Internet.

Table 1: Information about key informants.

\begin{tabular}{|l|l|l|l|l|l|l|l|}
\hline & Alice & Helen & Dora & Jennifer & Eva & Pauline & Regina \\
\hline $\begin{array}{l}\text { Island (birth/ } \\
\text { youth) }\end{array}$ & Santiago & Santiago & Sal & Santiago & Sal & $\begin{array}{l}\text { São } \\
\text { Vicente }\end{array}$ & $\begin{array}{l}\text { São } \\
\text { Vicente }\end{array}$ \\
\hline Age & $40 \mathrm{~s}$ & $30 \mathrm{~s}$ & $30 \mathrm{~s}$ & $50 \mathrm{~s}$ & $30 \mathrm{~s}$ & $50 \mathrm{~s}$ & $50 \mathrm{~s}$ \\
\hline Children & 3 & 1 & 2 & 2 & 1 & 4 & 3 \\
\hline $\begin{array}{l}\text { Last } \\
\text { occupation }\end{array}$ & Cleaner & Cleaner & Cleaner & $\begin{array}{l}\text { Shop } \\
\text { owner }\end{array}$ & Cleaner & Cleaner & $\begin{array}{l}\text { Café } \\
\text { owner }\end{array}$ \\
\hline Marital status & Single & Divorced & Single & Single & Married & Married & Single \\
\hline Relationship & $\begin{array}{l}\text { Helen's } \\
\text { Sister }\end{array}$ & $\begin{array}{l}\text { Alice's } \\
\text { Sister }\end{array}$ & --- & --- & $\begin{array}{l}\text { Tyra's } \\
\text { Mother }\end{array}$ & $\begin{array}{l}\text { Zhang's } \\
\text { Friend }\end{array}$ & --- \\
\hline
\end{tabular}

This study contains the testimonies of seven key informants (Table 1). They are firstgeneration Cape Verdean mothers who share the following characteristics: They left Cape Verde, some alone while others were sent for by trusted families or friends abroad, but all were single before the first act of emigration. They were born in Cape Verde but have worked abroad, typically in Portugal. They are currently employed and settled in Greater Lisbon. The youngest is in her early 30s. Secondary education is the highest qualification. The typical jobs of my principal informants are cleaning and domestic work. Two run small Cape Verdean-centred or African businesses. I included discussions about other Cape Verdeans where appropriate. Pseudonyms were used, and some names of places were omitted to protect anonymity. Although this sample is unsystematic and not fully representative of the Cape Verdean population, it is sufficiently representative for my limited purposes.

\section{Recipes of care and generosity: relationships in the making}

In many parts of the world, migration used to be a male rite of passage. The migrant woman is described by male participants in a Mozambican study as a "new man" who "is not a conventional male, but a female who now wears her husband's trousers." She is "womanmasculinized," a cold, violent, and incompetent wife and mother who has taken over her husband's roles (Raimundo, 2008, p. 199). Similarly, women are judged more harshly than men in family disputes (Staiano, 2013). In contrast to such popular representations, Caboverdianas are warm, caring and generous. They find pride and joy in motherhood.

Alice is a single mother in her 40s from Santiago. She has three children, two of whom were born in Cape Verde. The youngest boy has just started attending primary school. He was born after Alice had broken up with her boyfriend while living in a dilapidated Cape Verdean shantytown in Greater Lisbon. Alice and her three children already hold a Portuguese passport. I knew Alice through her cooking. She is a seasonal cook for associational and cultural 
activities. She is proud of her cooking skills and sells home-cooked katxupa, pastries and artisanal liquor. For her, cooking is about more than just making money, Alice explains that she is sometimes discriminated against because she does not speak Portuguese well; cooking is her retort to those who look down on her. Now renting a decent apartment, Alice reflects, "Mulher sem filhos não é ninguém. Mulher sem filhos é vazia." ("A woman without children is nobody. A woman without children is empty."). Alice is sceptical of voluntary childlessness. Her imagery of womanhood is plural, for a woman is always with her children. Alice provocatively exclaims, "Eu sou todo-poderosa!" ("I am all-powerful!"), when discussing her financial independence and hostility toward men.

I celebrated Christmas and New Year at Alice's home with her family and friends. On Boxing Day, I asked Alice's younger sister Helen how it was to be a mother. Her answer was instant. To be a mother is to be a superwoman who does everything. Helen is 30 years old and born on Santiago from a different father. She arrived from Angola soon after I met Alice. Though Helen's marriage with a white Portuguese-Angolan failed, she does not regret being a mother. Together with her pale-skinned, primary school-aged daughter, she stayed with Alice until she and her daughter found an apartment to rent. Cape Verdean mothers' decisions to relocate are often determined by their children's welfare. Helen moved from Angola to Portugal partly for the welfare of her only daughter. The child had been born in the city of Porto. Following the father, Helen then settled in rural Angola. There, her daughter often fell ill because of poor water quality. Helen enrolled her daughter in a private Portuguese school in Angola because she sensed that they would one day resettle in Portugal.Yet, Helen was not satisfied with the quality of teaching in Angola. She gave up a top managerial position in a private wine trading company. Although she formerly kept a maid and a chauffeur, now in Portugal, she is herself a live-out domestic helper and works part-time shifts in several homes during the week. When asked if she regrets her choice, she answers firmly, "Educação é a única coisa que os pais podem dar aos filhos." "Education is the only thing that parents can give to their children."). Helen justifies her decision on the basis that she now provides a significantly better environment for her daughter.

Caboverdianas are expected to provide for their children emotionally and financially so that being away is no excuse for neglect. Dora is in her early 30s. Dora left Cape Verde about five years ago. Her two daughters remained briefly in the care of their maternal grandmother on Sal. Dora had applied for a tourist visa for the Netherlands. As the naturalization procedure in the Netherlands is much stricter, she re-routed to Portugal. Dora counts every day up to when she will qualify for Portuguese nationality. About two years ago, the biological father of her two daughters took them with him to settle permanently in the United States with Dora's consent. The fact that he is from the Cape Verdean island of Fogo might explain his choice of emigration destiny. Dora explained to me that her former partner was jealous of her and wanted the two daughters to be close to him. He had known that Dora was applying for travel documents for the girls so that they would live with her in Portugal. Hearing the news, the father in America reacted and submitted applications to send for his children. Dora was angry at first. She eventually gave in because she believed that the children would have a better future and thrive there. Dora still provides mothering from a distance. Nonetheless, she orients her attention toward a different continent. She has never visited the United States.

Dora's story is illustrative for several reasons. The exchanges between mother and daughters are qualitatively different from before. Communication between two western countries such as the United States and Portugal is highly accessible and affordable. Dora enjoys posting photos that her daughters send via Facebook. Dora is proud of the academic excellence of her older daughter in an American public high school. Understandably, exchanges also have a financial lining to them. When asked if she remits money to the United States, Dora replies that when they were in Cape Verde, she sent money and other materials. In America, they have everything. They do not pay for school, transport or meals. Dora would 
be happy to send money, but their father rejects this. Therefore, Dora recognizes that her children no longer depend on her financially. This compels her to actively cultivate and deepen emotional intimacy. It also changes Dora's relationship with the father, which is a second reason why Dora's story is significant. Dora separated from him in Cape Verde because he was a womanizer. Now, Dora contacts him and maintains a cordial relationship with him. Dora's concession is comprehensible, given that her children are living with him, his married partner, and the latter's daughter. Reconciliation between ex-lovers is pragmatic and facilitated by a change in circumstances. Dora has been saving money for a year. Her daughters are coming to Portugal for a visit during the summer holiday. Without the father's consent, this visit would not be occurring. Yet another reason why Dora's example is worthy of analysis is that Dora learns about the United States from her daughters and subsequently plans to re-emigrate. Whereas it is taken for granted that teaching is done by adults and learning by children, the reverse is true in Dora's case. Dora is pleased with her daughters in America. She has gathered information about possible employment. Apparently, cooks are among the highest earners among unskilled and semi-skilled immigrants. She will enrol in a culinary course to learn cooking and finish secondary education in Lisbon. She eagerly awaits her elder daughter's approaching adulthood. Hopefully then the child will apply for reunification with her mother.

All my key informants belong to the working class and do not necessarily read and write well. Nonetheless, they harness the power of communication. Facebook, Skype and Viber are very popular, especially among migrants themselves. Jennifer was born in Santiago in the 1960s. In her youth, she was a female football player, represented Cape Verde and travelled frequently. She has legal residency in Portugal. She has run a shop selling hair care products in a metro station for two years. Although she lives alone in a rented apartment, she celebrates all important days of the year with one of her sons. From Monday to Saturday, Jennifer keeps regular hours. In the morning, she reads Portuguese newspapers. She spends the best part of every day on Facebook, sending and responding to messages, reading and commenting on posts, playing videos and giving likes to photos. Much of the public content involves Cape Verde, especially Creole music and scenery. The cash register is a web of cords, chargers, converters and plugs for a computer, a mobile phone and a tablet. Jennifer uses the free but weak metro station Wi-Fi. When the connection fails, she gets up, walks a little, blows her nose and stretches her arms. She is a friend of a Brazilian couple who run a café in the same metro station. There, she takes short breaks and treats friends who visit her. Jennifer likes to introduce me to her large family on Facebook. Judging by their surnames, some are from the father's side and others from the mother's. Jennifer is proud of her global network of maternal relations in Portugal, other European countries, and Cape Verde. Jennifer's birth father is a white Portuguese man, and most of Jennifer's paternal kin are now in the United States.

Indeed, family is brought together closer and faster by technology. At Alice's home on Christmas Eve, there was more talking than feasting. Using the Internet, Alice called her sisters and brothers in Cape Verde to wish them a Merry Christmas. Then she passed her mobile phone across the table to her sister Helen and the conversation continued. The moment the call ended, Helen initiated a video chat on her phone and resumed the conversation with the same people in Cape Verde. As Alice had just become a grandmother for the first time, she hugged her two-month old grandchild and presented her to her Cape Verdean family. Next, it was the turn of the nephews and nieces. Alice announced repeatedly with great pleasure in Portuguese and Creole her planned trip to Cape Verde in the coming summer, "God willing, next year, we'll be together as one." On New Year's Eve, the good wishes and good news were restated. Around midnight, mobile phones started ringing. Alice instantly called her family in Cape Verde to wish them Happy New Year and reinforce her Christmas messages. She insisted on checking all the notes from well-wishers on her phone before going to bed. Technology has enabled migrant women to expand their social networks transnationally and include their family within this expanded network. 
For Caboverdianas, togetherness and emotional support are fundamental to well-being. Eva's family was originally from São Nicolau, but Eva was born and raised on Sal. She studied catering and hotel management with a scholarship in a vocational school close to Portugal's border with Spain in the late 1990s. Eva went through multiple episodes of discrimination. She was the only African in her course and her colleagues provoked her maliciously. She was called names in the street and told to walk in the rain to wash her skin white. Nonetheless, looking back at the older days, Eva sighs that there were very few Cape Verdean students in different schools or courses, and Portuguese in the north were not accustomed to seeing Africans. Though thankful for the education, she travelled down to Greater Lisbon for a more diverse and accepting environment. Now, on weekends when she prepares feasts in her home, there is an interesting mix of Cape Verdeans, Angolans, Santomeans, Portuguese, and others.

I have often heard confessions of loneliness from Caboverdianas. One way to counter these feelings is through the circulation of care (Badassar \& Merla, 2014). Eva has no close relations in Portugal. Her only daughter, Tyra, was born in Greater Lisbon. Relationship with the biological father has soured. Eva's boyfriend works in France and visits her in Portugal intermittently. They would like to get married someday. Eva lives with her daughter Tyra in a rented three-room apartment, so there is extra space. Last summer, Eva's mother came to stay with her. In November, her mother complained about rheumatism, the cold weather and saudades de Cabo Verde (longing for Cape Verde). Eva wanted her to stay, but she returned to her other children on Sal. Eva's siblings had paid for the first trip. Eva was responsible for the documents and the return trip to Cape Verde. Eva thought it was worth the trouble for several reasons. First, Eva has no siblings in Portugal. She always complains about solitude. Second, she works from midday to midnight as a cleaner in a car factory and her daughter needs care. Therefore, Tyra's grandmother was a great help. Then, as Tyra was born in Portugal and has yet to visit Cape Verde, this was an opportunity to cultivate grandmother-granddaughter intimacy. Eva considered it a money-saving decision. She reasoned that it was cheaper to bring her mother over than two of them going to Cape Verde. She wished that her mother had stayed longer, but she had left early because it was very cold in Portugal. Living costs on Sal are extremely high due to tourism. Basic necessities, especially if they are packaged and commercialized, are more affordable in Portugal.

Migration exposes migrant women to fresh faces. Frequently, migrant women learn to meet people with whom they would not have interacted if they were in their homeland. The following considers the intercultural relationships that Caboverdianas develop abroad. Pauline was born on Santo Antão. When Pauline was only a baby, her mother relocated to São Vicente. Pauline came to Portugal with an uncle as an adolescent. Though Pauline complained that her uncle only wanted her to work for him, it was because of him that Pauline became the first child in her family to leave Cape Verde. Later, Pauline was able to help her other siblings to emigrate. Pauline currently lives with two sons and her husband in an apartment the couple bought. Pauline is in her early 50s. She miscarried twice and has four surviving children, all born in Portugal, from at least three fathers. Pauline's youngest son was born after the couple moved into the current residence, but before the couple tied the knot.

Pauline had a memorable friendship with Zhang. Zhang was born in colonial Mozambique, an ethnic Chinese with Portuguese nationality. He was a boxer. He moved to Portugal, remaining childless and estranged from his family and relatives. Pauline befriended Zhang in the ophthalmology department of a hospital. Her adolescent son, now in his late 30s and permanently blind, was hospitalized after a car accident. At the time Zhang appeared, Pauline's apartment was crowded. There were only three rooms for eight people: Pauline, her husband, Pauline's eldest daughter, three sons, Pauline's goddaughter and Zhang. The appetite of the enlarged household was great. Pauline bought two crates of fruit in a wholesale market every week. Milk and potatoes were consumed rapidly. When Zhang lived with Pauline, he did not pay rent. As a conscientious Chinese, Zhang cooked and cleaned the kitchen every 
day when Pauline went to work. He bought a lot of lottery tickets and promised Pauline that if he won, he would buy her a big apartment with a better kitchen. He called Pauline 'lady', and others commented that Pauline had a 'Chinese father'. Eventually, Pauline helped Zhang apply for Portuguese social security benefits and find an affordable care centre. Pauline visited Zhang at the centre regularly, or he would come to her apartment. Zhang died in his 80s. Up to this day, Pauline visits the cemetery where Zhang is buried. The friendship between Pauline and Zhang is significant. There was mutual trust. Pauline was the Zhang's de facto family. I have heard some Cape Verdeans speak of suspicions that Chinese people never die because they have never seen a Chinese funeral, or that they do not dare eat in a Chinese restaurant because the meat could be human flesh. Pauline trusted a Chinese man and treated him as someone older and more knowledgeable. The friendship between Pauline and Zhang positively influenced the others. Even today, Pauline and her family remember Zhang fondly and praise his optimism and agility, recalling things he taught them about China. For instance, they know how to read a Chinese name and locate the surname correctly, which is rare in Portugal.

Caboverdianas have very diverse work experiences. While Portuguese stigmatize unskilled occupations and prefer one stable job, Caboverdianas are surprisingly open about employment opportunities. They are prepared to take up new jobs and rarely worry about peer comparisons. Pauline, for example, is a jack-of-all-trades. She has been a cleaner, cook and singer. She has worked in private homes, an elderly care centre and a nursery. She was a recreation club owner. In another case, Regina, a shapely grandmother, is from São Vicente. In Portugal, Regina works hard to bring over her three grown children. Regina was employed in an old age home. Unlike most of her colleagues, what is interesting is that Regina derived pleasure from her work. She did not leave because of a dislike for her work but instead because circumstances forced her to give up. When she worked night shifts, she could not catch the bus home and had to sleep in the centre. Recalling her time there, Regina was an assistant who, when the nurses were unavailable, assumed responsibility for feeding and monitoring the elderly residents. She also had to teach the younger staff. Regina recognized the burden she had on her small shoulders. She took it seriously and told stories about old people who had died in care centres because of human error or neglect. She says of her patients and friends, "São vidas que não sabem defender-se." ("Those are undefended lives."). Regina, who does not use the Internet, still keeps photos of her patients on her old mobile phone.

Regina celebrated the first anniversary of the café close to my home - her first business venture. There are a dozen identical coffee shops catering to the same clientele alongside and close to Regina's. Regina has no clients from the windward islands; instead, her customers are working-class Portuguese, Indians, male badius (poor, dark-skinned Cape Verdeans), other Africans and minority groups. Many are construction workers, petty traders, or people who are unemployed or retired. Some are at times drunk and at times rowdy. I was told that the success of Silvia's café was due to personal beauty, character and care. Regina is an interesting case. She has learned to trust people who in Cape Verde are considered different. Regina has two badius to run errands: buying ingredients, delivering food to neighbours, dispatching drunkards and paying miscellaneous expenses. They keep Regina good company and have free meals and liquor in the café. In fact, Regina had a badiu boyfriend who worked normally during the day and came to manage the café from late afternoon to around midnight so that Regina could sleep. Recently, Regina happily announced to her clients that she has a new boyfriend, "Arranjei um guineense." ("I've got a Guinean boyfriend.”). Furthermore, Regina often goes out of her way to care for Senhor Mateus, a decrepit lonesome badiu who often neglects his personal hygiene. While he is in the café, Regina constantly sprays air refresher to lighten the odour. When the sky darkens, Regina reminds him of the time. She understands that the man has failing eyesight and may fall on the road on the way home. Every Monday, Regina is legally obliged to close her café, but asks people to take soup, fish and red wine to Senhor Mateus. When I enquired if the man does not eat elsewhere, I was told, "Come, mas 
não come bem." ("He eats, but he does not eat well."). The intercultural relationships that Caboverdianas develop abroad are diverse and heartening.

\section{Making it home: the negotiation of relationships between territories}

Place is an important contributor to identity. Migrant women can develop attachments to places in a foreign land. My fieldwork reveals that Caboverdianas learn to love where they work and live. Helen, Alice's younger sister, is a very independent woman, partly because of her upbringing and experience. At 19, Helen was the first and youngest child to emigrate. She lived near Lisbon briefly. Then, she settled in Porto for three years. There, she was enrolled in a one-year, non-degree management program, met her white Portuguese-Angolan husband and gave birth to her daughter. Eventually, Helen followed him and re-emigrated to Angola. When their relationship failed, Helen moved out with her daughter but continued to live and work in rural Angola. There were few Cape Verdeans in her circle of friends where Helen was settled. I learned a lot about Angola from Helen. She often repeats her motto, "Eu gosto de aprender sobre outras culturas." "I enjoy learning about other cultures.").

Helen has an ambiguous relationship with Angola, an adopted country, in several ways. At first, she was curious about Angola and eager to learn about its history and ethnicities. Her enthusiasm even surpassed that of the locals. Helen describes her thirst for knowledge with the following words, "Eu gostava de aprender a história da Angola. Queria saber como era Angola antes de os portugueses chegarem. Mas ninguém conseguiu explicar-me. Não encontrei respostas nos livros. Os próprios angolanos não sabem a história de Angola." "'I'd like to learn the history of Angola. I'd like to know what Angola was like before the Portuguese arrived. But nobody could explain to me. I could not find answers in books. Not even the Angolans know the history of Angola."). Second, she also travelled to neighbouring Namibia. She distinguishes between Angolans and Africans from nearby countries, knows what businesses they deal in and what arts originate from which people. She explains the manifestations of discrimination in various African states based on her personal experience as a brown creole woman with a white child. Helen is concerned about many issues in Angola and in other parts of the world and does not shy from making criticisms.

Porto was the city of Helen's youth. She enjoyed her stay there. It was where her daughter was born. She cherishes the short management course she took, not so much for the knowledge she gained, but because of her experience in an academic environment with likeminded young people. This positive experience nurtures in Helen the constant hope that she will one day really attend university. She expresses the desire to live in Porto again at some future time. Helen does not regret giving up her well-paid position in Angola. She evaluates Portugal positively, "Portugal é Saúde, Segurança e Liberdade." ("Portugal is Health, Security and Liberty."). Her child is entitled to quality public health care and education. Furthermore, Portugal is a democratic country that respects freedom. Of the three qualities, liberty is probably the most important. Helen values freedom above material comfort, saying that "Se um dia Portugal deixar de ser um país livre, vou-me embora. Não posso perder a liberdade." "If one day Portugal stops being a free country, I'll go away. I can't bear losing my liberty.").

The African side of Cape Verde has been silenced (Henriques, 2016). It is a major polarizing factor in the divide between the windward and leeward islands. Cape Verdeans generally distinguish between the windward and leeward islands and, moreover, identify with a particular island. There are two opposing reference points: Santiago is represented by the figure of the badiu, the dark and illiterate farmer from the countryside who dances to the beats of batuque. Meanwhile, São Vicente is the Europe of Cape Verde. Its capital hosts educated, pale-skinned creoles, leisurely office workers, and civil servants (Vasconcelos, 2012, p. 8). The distinctions between island origins are social rather than given. Almost all my principal informants have ties with more than one island. This is the norm, rather than the exception, echoing earlier discussions about actively performing or doing islandness (Vannini \& Taggart, 
2013). The women fall under one or more of four categories: (1) they were born on one island but raised on another; (2) their current companion is from a different island; (3) they have children with men from different islands; and (4) they worked and travelled between islands.

For instance, Jennifer falls under the last category. Recalling her story, Jennifer runs a metro station shop that sells hair care products. Jennifer was originally from Santiago. In her youth and before settling permanently in Portugal, she belonged to a female football team that played both in Cape Verde and abroad. Jennifer declared, "Já joguei futebol em todas as ilhas, menos Santa Lucia." ("I played footfall on all the islands, except Santa Lucia."). This last island is uninhabited. Jennifer represented Cape Verde in various European countries. Jennifer also learned self-defence at an academy in which she made friends with Cape Verdeans from all over the country who now occupy important public positions. On Facebook, Jennifer follows the expeditions and gatherings that the academy organizes and recognizes the people who were once her colleagues and with whom she has lasting friendships. She dearly loves her home town of Órgãos on Santiago, but she appreciates all the islands of Cape Verde.

Dora is another example of Caboverdianas who have ties with more than one island. She easily fits in all four of the aforementioned categories. Currently, she is a live-out domestic helper in the home of a Brazilian dentist and white Angolan manager. Dora was born in São Vicente. Soon after she was born, her mother moved to Sal to work and took Dora with her. Dora was raised on Sal. Her current boyfriend is from São Vicente. They share a two-room apartment with a niece, who is only one year younger than her, and the niece's boyfriend (both of whom are from São Vicente). The biological father of Dora's two daughters is from Fogo. As a young adult, Dora also travelled between islands to search for greener pastures. Dora is conscious that she has had rich migratory experiences. She classifies herself as a nomad. Dora was pregnant with her first daughter when she was 18 and did not finish secondary education in Cape Verde. Notwithstanding, she reads Creole texts with impressive fluency. Dora likes to read stórias, or old anecdotes, written in kriolu badiu (Creole of Santiago). She compares herself with her niece. Because of her inter-island exposure, Dora knows and appreciates the varieties that exist in the Cape Verdean language. Meanwhile, her niece only understands kriolu sampadjudu (Creole of the windward islands) because she only knows one island. It seems logical to suggest that for Caboverdianas with rich migratory experiences, island identity is a conscious personal choice, that is, if they at all prefer one island over others.

Migration and return complement each other. Migration comes full circle. Heidegger (2001) delved into the core meaning of the activity of building. To be in the world is to dwell. People are essentially dwellers. This a priori human condition is what circumscribes and necessitates building. If we understand kinship as daily feeding and nurturing processes, the house is the principal unit in which kinship is performed (Carsten \& Huge-Jones, 1995). Elaborating on the house projects of Albanian emigrants working in Greece, Dalakoglou (2010) distinguishes between 'building' and 'making' a house. The former is done for others and the latter for oneself. When the emigrants 'make' a house in Albania, they undertake a personal life project and a life-long commitment to Greece. Sampaio (2013) presents a credible ethnographic account of how Cape Verdean men built houses in 6 de Maio, an illegal Cape Verdean settlement along Estrada Militar on the periphery of Lisbon. The house keeps women and children and affirms the masculinity and success of men. The help of fellow Cape Verdean men, or Djunta-mon, is much depended upon. The house-project is of utmost importance to Cape Verdean men. It is rather unfortunate that women are largely invisible in this important undertaking. As I show below, however, Caboverdianas also appropriate the house project to signal maturity and independence. 


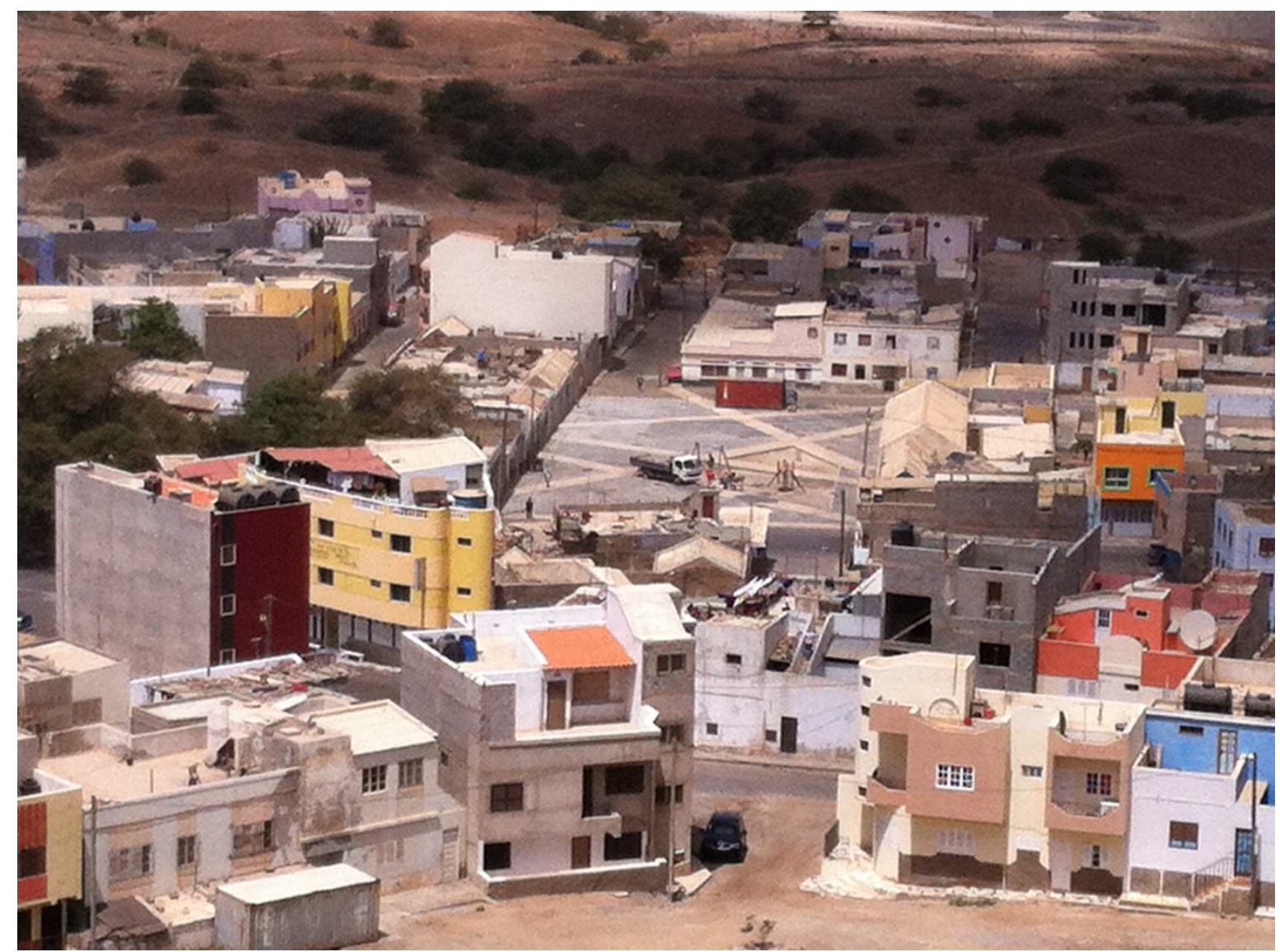

Figure 3: Houses in different stages of construction on Sal island, Cape Verde. (C) Kaian Lam

Dora applied for a plot of land from the local authority on Sal about seven years ago, that is, before she moved to Portugal. In 2015, she received news from her mother that her application had been approved. Dora showed me the original letter of application from 2008. So many years had passed that Dora had almost given up hope. Dora represents an interesting case. Dora had a room in her mother's house and she shared a house with the father of her two daughters on Sal, but she insists that she will make her own home. Dora's former companion was a barber. One time he cut the hair of the Prime Minister and asked for a piece of land, and his wish was granted the day after. Dora helped to make their home, and she moved in with her daughters. The pair later separated, and Dora gave up her claim on the house. According to Dora, he was abusive and threatened her and her daughters. So, she gave him the house. Dora explains that that house is no longer hers and she will make her own house. Had Dora not migrated, she would not have had the financial capacity and felt the urge and courage to realize such a significant, large-scale project. It seems logical to say that Dora's determination to make her home in Cape Verde reflects her newly-gained independence as a result of hard work and dedication yet that some men perceive this as a form of threatening 'maleness'.

When I ask Caboverdianas if they have a casa (the same word for home or house as in Portuguese) in Cape Verde, the answer is always positive. Whereas many migrants do make their own home, others identify the house in which they grew up as their home. The two sisters Alice and Helen grew up in their maternal grandmother's house in Tarrafal, Santiago. They call their grandmother 'mamã'. Their mother died in an accident shortly after Helen was born. Helen sometimes sighs, "Eu não tenho mãe." ("I don't have a mother."). At times, Alice laments that she lost her mother early. Therefore, the grandmother is especially important to Helen, who has scarcely any memory of her mother, as well as to Alice. For both, their Cape Verdean home is their grandmother's house. Neither express an intention to make their own 
home in the future. Helen is more critical though. She judges that there is no love when people are obsessed about home ownership. She thinks that partners and their children should live together and rent instead; people must modernize and change with the times.

\section{Conclusions}

This study adopted a transnational perspective to the study of lived experiences, relationships and expressions of womanhood. It elaborated on how Caboverdianas reconfigure their relationships with people and their imaginings of places. They negotiate their physical absence and rethink their mothering practices and other family duties. The very concept of mothering is rejuvenated. Technologies allow the expansion and complexification of human networks. Caboverdianas learn to take care of their emotional health and cope with solitude. They become more accommodating to the foreignness in their own culture and more accepting of other cultures and peoples. Permanence in a place and participation in its society unavoidably mark personal development and contribute to the formation of an international outlook. Caboverdianas constantly reflect on their own upbringings and negotiate their position in their own culture and society. They reassess their relationships with their country, their compatriots, and the islands within the archipelago from which they originated. They construe imageries of the casa in accordance with personal aspirations, evolving life goals and migration experiences. Home-making is appropriated to signal belonging, individuality and change.

It is hoped that this study has provided a valuable glimpse into the lives of migrant islander women in a mainland metropole. I suggest that migrant women are historically, socially and culturally situated subjects. Not only do they possess the capacity to forge meaningful relationships, but they also navigate a sea of multiple and overlapping identities and belongings. They redefine womanhood and give it brave new expressions. This means that they demonstrate self-confidence in what they do well, not just as daughters, mothers or dependable friends, but also as cooks, feast organizers, neighbourhood diplomats and cultural ambassadors. At times, this signifies defiance of social taboos. Ideas of modernity and female liberation are captured in flourishing creolized expressions of openness, hope and earnestness to live happily and feel accomplished. Caboverdianas, although originating from different islands, nonetheless have a global worldview. This metamorphosis is achieved transnationally.

Caboverdianas are island-raised but foreign-made. The growth of Caboverdianas starts on the islands but is completed abroad. They are integral and well-rounded individuals with an island memory and sensibility at the core, enriching and condensing layers of international exposure.

\section{Acknowledgements}

My sincere gratitude to Luís Batalha, Celeste Quintino and Sónia Frias for their professional guidance. A version of this paper was presented at the 5èmes Rencontres Scientifiques des Études Africaines en France in July 2018.

\section{References}

Åkesson, L., Carling, J., \& Drotbohm, H. (2012). Mobility, moralities and motherhood: navigating the contingencies of Cape Verdean lives. Journal of Ethnic and Migration Studies, 38(2), 237-260. https://doi.org/10.1080/1369183X.2012.646420

Andall, J. (1999). Cape Verdean women on the move: 'immigration shopping' in Italy and Europe. Modern Italy, 4(02), 241-257. https:// doi.org/10.1080/13532949908454832

Appadurai, A. (1996). Modernity at large: cultural dimensions of globalization. New York: University of Minnesota Press. 
Badassar, L., \& Merla, L. (Eds.). (2014). Transnational families, migration and the circulation of care: understanding mobility and absence in family life. New York: Routledge.

Baldacchino, G. (2008). Studying islands: on whose terms? Some epistemological and methodological challenges to the pursuit of island studies. Island Studies Journal, 3(1), 37-56.

Baldacchino, G. (2013). Island landscapes and European culture: an "Island Studies" perspective. Journal of Marine and Island Cultures, 2(1),13-19.https://doi.org/10.1016/j.imic.2013.04.001

Batalha, L. (2004). The Cape Verdean diaspora in Portugal: colonial subjects in a postcolonial world. Lanham: Lexington.

Batalha, L., \& Carling, J. (Eds.). (2008). Transnational archipelago: perspectives on Cape Verdean migration and diaspora. Amsterdam: Amsterdam University Press. https://doi.org/10.5117/9789053569948

Bourdieu, P. (1984). Distinction: a social critique of the judgement of taste. London: Routledge.

Carreira, A. (1977). Migrações nas ilhas de Cabo Verde. Lisbon: Universidade Nova de Lisboa.

Carreira, A. (1984). Cabo Verde: aspectos sociais. secas e fomes do século XX (2nd ed.). Lisbon: Ulmeiro.

Carsten, J., \& Huge-Jones, S. (Eds.) (1995). About the house: Lévi-Strauss and beyond. Cambridge: Cambridge University Press. https://doi.org/10.1017/CBO9780511607653

Certeau, M. de (1984). The practice of everyday life. Berkeley: University of California Press.

Challinor, E.P. (2015). In dialogue with self and the world: Cape Verdean migrant pregnancy in Portugal. Women's Studies International Forum, 52, 63-70. https://doi.org/10.1016/j.wsif.2015.06.003

Compan, M. (2018). "Mayotte: an explosive confetti": anchorage and drift of Comorian identity. Paper presented at Congresso Internacional: Insularidades e Enclaves em Situações Coloniais e Pós-coloniais. Trânsitos, Conflitos e Construções Identitárias Séculos XV-XXI. Lisbon: University of Lisbon.

Dalakoglou, D. (2010). Migrating-remitting-'building'-dwelling: house-making as 'proxy' presence in postsocialist Albania. Journal of the Royal Anthropological Institute, 16(4), 761777. https://doi.org/10.1111/j.1467-9655.2010.01652.x

Ducros, H.B. (2018). Reclaiming islandness through cloth circulation in Madagascar. Island Studies Journal, 13(2), 25-38. https://doi.org/10.24043/isj.69

Garfield, R. (2015). Three islands of the Portuguese Atlantic: their economic rise, fall and (sometimes) rerise. Shima, 9(2), 47-59. http://doi.org/10.21463/shima.12.1.09

Glick Schiller, N., Basch, L., \& Blanc-Szanton, C. (1992). Transnationalism: a new analytic framework for understanding migration. Annals of the New York Academy of Sciences, 645, 1-24. https://doi.org/10.1111/j.1749-6632.1992.tb33484.x

Góis, P. (2005). Low intensity transnationalism: the Cape Verdian case. Vienna Journal of African Studies, 8(5), 255-275.

Grassi, M., \& Évora, I. (Eds.) (2007). Género e migrações cabo-verdianas. Lisbon: Imprensa de Ciências Sociais.

Grydehøj, A. (2018). Islands as legible geographies: perceiving the islandness of Kalaallit Nunaat (Greenland). Journal of Marine and Island Cultures, 7(1), 1-11. https://doi.org/10.21463/jmic.2018.07.1.01

Hall, S. (1996). New ethnicities. In D. Morley \& K.H. Chen (Eds.) Stuart Hall: critical dialogues in cultural studies (pp. 441-449). London: Routledge.

Hannerz, U. (2003). Being there... and there... and there! Reflections on multi-site ethnography. Ethnography, 4(2), 201-216. https://doi.org/10.1177/14661381030042003

Heidegger, M. (2001). Building dwelling thinking. In Poetry, language, thought (pp. 141-159). New York: Harper Perennial.

Henriques, G. (2016). Ser africano em Cabo Verde é um tabu. Público, 1 January. https://www.publico.pt/mundo/noticia/ser-africano-em-cabo-verde-e-um-tabu-1718673

Lobo, A. (2014). "Just bring me a little letter": the flow of things in Cape Verde transnational family relations. Etnográfica, 18(3), 461-480. https://doi.org/10.4000/etnografica.3788 
Morokvasic, M. (1984). Birds of passage are also women... The International Migration Review, 18(4), 886-907. https://doi.org/10.2307/2546066

Nolasco, A. (2018). Designing national identity through cloth: pánu di téra of Cape Verde. Island Studies Journal, 13(2), 9-24. https://doi.org/10.24043/isj.65

Oliveira, T.S. de. (2018). Inkumenda di téra: the informal circulation of Cabo Verdean food products. In D. Mata-Codesal \& M. Abranches (Ed.) Food parcels in international migration. Intimate connections. (pp. 169-190). London: Palgrave Macmillan. https://doi.org/10.1007/978-3-319-40373-1 8

Pugh, J. (2013). Island movements: thinking with the archipelago. Island Studies Journal, 8(1), $9-24$.

Raimundo, I. (2008). The interaction of gender and migration household relations in rural and urban Mozambique. Codesria Gender Series Masculinities in Contemporary Africa, 7, 191-208.

Sampaio, C. (2013). Habitar o 6 de Maio: as casas, os homens, o bairro. Unpublished master's thesis. Institute of Social Sciences, University of Lisbon, Lisbon.

Seibert, G. (2014). Crioulização em Cabo Verde e São Tomé e Príncipe: divergências históricas e identitárias. Afro-Ásia, 49, 41-70. https://doi.org/10.1590/S0002-05912014000100002

Silva, C., \& Fortes, C. (Eds.) (2011). As mulheres em Cabo Verde: experiências e perpectivas. Praia: Universidade de Cabo Verde.

Staiano, F. (2013). Good mothers, bad mothers: transnational mothering in the European Court of Human Rights' case law. European Journal of Migration and Law, 15(2), 155-182. https://doi.org/10.1163/15718166-12342029

Vale, C. (2018). Understanding island spatiality through co-visibility. Shima, 12(1), 79-98. https://doi.org/10.21463/shima.12.1.09

Vannini, P., \& Taggart, J. (2013). Doing islandness: a non-representational approach to an island's sense of place. Cultural Geographies, 20(2), 225-242. https://doi.org/10.1177/1474474011428098

Vasconcelos, J. (2012). “Manera, ess muv?”: a mobilidade como valor em São Vicente de Cabo Verde. In J.B. Dias \& A. Lobo (Eds.) África em movimento (pp. 49-62). Brasília:ABA.

Welsch, W. (1999). Transculturality: the puzzling form of cultures today. In M. Featherstone \& S. Lash (Eds.) Spaces of culture: city, nation, world (pp. 194-213). London: Sage. https://doi.org/10.4135/9781446218723.n11

Williams, R. (1983). Keywords: a vocabulary of culture and society (2nd ed.). London: Fontana. 